\title{
Characteristic differences of chest pain in male and female patients with acute coronary syndrome: A pilot study
}

\author{
Yurike Olivia Sella, ${ }^{1}$ Halidah Manistamara, ${ }^{1}$ Sony Apriliawan, ${ }^{1}$ Mifetika Lukitasari, ${ }^{1,2}$ \\ Mohammad Saifur Rohman ${ }^{2,3,4}$
}

\begin{abstract}
${ }^{1}$ School of Nursing, Faculty of Medicine, Universitas Brawijaya, Malang; ${ }^{2}$ Cardiovascular Research Group, Faculty of Medicine, Brawijaya University, Malang; ${ }^{3}$ Department of Cardiology and Vascular Medicine, Faculty of Medicine, Universitas Brawijaya; ${ }^{4}$ Saiful Anwar General Hospital, Malang, Indonesia
\end{abstract}

\begin{abstract}
Background: The typical sign or main symptom in acute coronary syndrome (ACS) patients is chest pain, which is an initial benchmark or early sign for diagnosis. Certain factors, such as gender differences, the presence of diabetes mellitus or other clinical conditions, may make the patient not realize they have ACS. Therefore, this study aims to identify the characteristics of chest pain symptoms in male and female patients with ACS.

Design and Methods: This is a non-experimental quantitative study, namely analytical observation using a cross-sectional approach within 4 months (January-April 2019). Furthermore, the samples were 53 ACS patients (28 male and 25 female).

Results: The chest pain characteristics that have a significant relationship with gender differences in ACS patients are shown based on the aspects of location, pain duration and quality. Male patients are more likely to feel pain at the left or middle chest, the duration is between $<20$ to $>20$ min with moderate pain quality, which tends to become severe, while females are more likely to feel pain at the chest which radiates to the neck and chin, the duration is usually $>20$ min, with mild to moderate pain quality.

Conclusions: The result showed a significant difference in chest pain characteristics in male and female patients with ACS. Regarding location, duration and quality of chest pain, male ACS patients mostly have more typical symptoms, while females' symptoms are atypical.
\end{abstract}

\section{Introduction}

Cardiovascular disease is the major cause of disability and death in both males and females in the world. In fact, this condition is the leading cause of death from all non-communicable diseases, and is responsible for 17.5 million deaths in the world or $46 \%$ of all non-communicable disease deaths. Also, it is estimated that 7.4 millions of these deaths are caused by ischemic heart disease. ${ }^{1}$ Based on research data from the Jakarta Acute Coronary Syndrome (JACS) Registry, there were a total of 1223, 1915, and
1925 patients with ACS in 2007, 2010 and 2013, respectively, which were classified as acute coronary syndrome NSTEMI (nonST elevation myocardial infarction). ${ }^{2}$ This figure shows that ACS increases every year, and based on the ACS Registry at a general hospital in Malang, East Java, Indonesia, it was found that at least 1-2 people are hospitalized daily for ACS. Acute coronary syndrome requires immediate diagnosis and management to prevent more severe complications. ${ }^{3,4}$ The typical sign or main symptom that appears in the patients is chest pain, therefore this presentation can be used as an initial benchmark to detect ACS. Early identification and accurate symptoms interpretation are difficult for non-professionals, especially when the symptoms deviate from what the patient believes to be normal, or the symptoms are similar to other non-cardiac conditions..$^{5-7}$ Also, chest pain characteristics can be ambiguous, especially in certain special conditions such as gender differences, diabetes mellitus or other diseases, hence the patient might not realize they have ACS. Therefore, it is important for high-risk individuals or patients to know the signs and symptoms of ACS, since it has been frequently associated with late treatment or prehospital delay. ${ }^{8-10}$

There are many variations in chest pain symptoms between male and female with regards to the aspects of location, nature, and additional symptoms. ${ }^{11-13}$ Meanwhile, females primarily experience more atypical symptoms. ${ }^{14}$ The difference in symptom manifestations reported in males and females with ACS in previous study, ${ }^{15}$ is known to be due to the process of chest pain transmission mechanisms which is mediated by sympathetic and vagal nerves activation. There are still no studies that focus on examining the characteristic difference of chest pain symptoms in male and female patients with ACS in Indonesia. Therefore, this study aims to describe the characteristics difference of chest pain in male and female patients with ACS.

\section{Design and Methods}

This is a non-experimental quantitative study, namely analytic observation using a cross sectional approach conducted at general

Significance for public health

There are various characteristics of chest pain differences between male and female patients with Acute Coronary Syndrome. The findings of this study showed that it is important to provide optimal nursing care and also educate patients and families about the signs, or symptoms that often occur, especially atypical symptoms. This will reduce the tendency to delay in seeking treatment, which will affect prehospital delay time. 
hospital in Malang for 4 months (January-April 2019). Furthermore, the respondents were selected using purposive sampling technique. The inclusion criteria were: i) medical diagnosis of STEMI and NSTEMI; ii) free of chest pain (angina) for 24 hours for those with myocardial infarction; iii) hemodynamically stable; iv) not diagnosed with acute decompensated heart failure (ADHF); v) does not have malignant arrhythmias; vi) not in acute lung oedema (ALO) state; vii) not on ventilator; viii) willing to become respondents. Meanwhile, the exclusion criteria were: i) patients with various complications; ii) ACS patients with diabetes mellitus. Based on the inclusion and exclusion criteria, the sample size of 53 patients was obtained. This study used the chi-square statistical test to analyze the demographic characteristics and differences in chest pain in male and female patients with ACS. Also, the questionnaire was obtained from modified flowchart (SCORE Chart). In addition, ethical research was approved by the ethics committee of dr. Saiful Anwar hospital, Malang.

\section{Results and Discussions}

Patient baseline characteristics being observed include age, menopause, marital status, education, occupation, type of payment, BMI, clinical history and medical diagnosis. Table 1 shows the distribution analysis result of baseline characteristics of ACS patients. The number of respondents were 53 patients ( 28 male and 25 female). Based on Table 1, it can be seen that in the patient's demographic data, only points of marital status, occupation, clinical history of smoking, history of hypertension and medical diagnosis have a significant relationship with gender differences $(\mathrm{p}<0.05)$ (Table 1). Table 2 shows the differences in chest pain characteristics that can be seen in male and female patients with ACS. The results showed that out of the 6 aspects covered as chest pain characteristics, only 3 aspects that had a significant relationship $(\mathrm{p}<0.05)$, namely location, duration and pain quality. In addition, Table 3 showed that out of the 5 accompanying symptoms that occur in ACS patients, only 2 are significantly related to gender differences $(\mathrm{p}<0.05)$, which is abdominal pain and diaphoresis (Table 3). There are 6 chest pain characteristics aspects in this study which consist of location, cause, duration, character/nature, quality and history. However, this study showed that location, duration and quality had significant correlations with gender differences $(p<0.05)$. Based on the pain location, it was found that males with ACS tend to experience pain in the left or middle chest compared to female patients, while females felt more pain in the chest area radiating to the neck and chin. This data is directly proportional to previous studies, ${ }^{16-18}$ that demonstrated pain in the middle part of chest is more experienced by males with a $p<0.01$ and female patients experience pain in form of radiations to the

Table 1. Baseline characteristics.

\begin{tabular}{|c|c|c|c|c|}
\hline Respondent characteristics & & $\begin{array}{c}\text { ACS patients } \\
\text { Male } \\
(n=28)\end{array}$ & $\begin{array}{l}\text { Iffer chest pain } \\
\text { Female } \\
(\mathrm{n}=25)\end{array}$ & p \\
\hline Age & & $55.82 \pm(12.772)$ & $62.92 \pm(9.363)$ & 0.509 \\
\hline Menopause & & - & $20(80 \%)$ & - \\
\hline Marital status & & & & 0.044 \\
\hline Married & $44(83 \%)$ & $26(92.9 \%)$ & $18(72 \%)$ & \\
\hline Widow & $9(17 \%)$ & $2(7.1 \%)$ & $7(28 \%)$ & \\
\hline $\begin{array}{l}\text { Educational background } \\
\text { Non completed elementary school } \\
\text { Elementary school } \\
\text { Junior high school } \\
\text { Senior high school } \\
\text { University }\end{array}$ & $\begin{array}{c}2(3.8 \%) \\
10(18.9 \%) \\
16(30.2 \%) \\
20(37.7 \%) \\
5(9.4 \%)\end{array}$ & $\begin{array}{c}1(3.6 \%) \\
5(17.9 \%) \\
6(21.4 \%) \\
13(46.4 \%) \\
3(10.7 \%)\end{array}$ & $\begin{array}{c}1(4 \%) \\
5(20 \%) \\
10(40 \%) \\
7(28 \%) \\
2(8 \%)\end{array}$ & 0.585 \\
\hline $\begin{array}{l}\text { Occupation } \\
\text { Civil servant } \\
\text { Private servant } \\
\text { Entrepreneur } \\
\text { Unemployed }\end{array}$ & $\begin{array}{c}3(5.7 \%) \\
14(26.4 \%) \\
9(17 \%) \\
27(50.9 \%)\end{array}$ & $\begin{array}{c}3(10.7 \%) \\
10(35.7 \%) \\
7(25 \%) \\
8(28.6 \%)\end{array}$ & $\begin{array}{c}0(0 \%) \\
4(16 \%) \\
2(8 \%) \\
19(76 \%)\end{array}$ & 0.005 \\
\hline $\begin{array}{l}\text { Payment type } \\
\text { General } \\
\text { JKN } \\
\text { Employment insurance } \\
\text { Personal insurance } \\
\end{array}$ & $\begin{array}{c}11(20.8 \%) \\
38(71.7 \%) \\
4(7.5 \%) \\
-\end{array}$ & $\begin{array}{c}7(25 \%) \\
18(64.3 \%) \\
3(10.7 \%) \\
-\end{array}$ & $\begin{array}{c}4(16 \%) \\
20(80 \%) \\
1(4 \%) \\
-\end{array}$ & 0.415 \\
\hline $\begin{array}{l}\text { Body mass index } \\
\text { Normal } \\
\text { Overweight }\end{array}$ & $\begin{array}{l}41(77.4 \%) \\
12(22.6 \%)\end{array}$ & $\begin{array}{c}22(78.6 \%) \\
6(21.4 \%)\end{array}$ & $\begin{array}{c}19(76 \%) \\
6(24 \%)\end{array}$ & 0.823 \\
\hline $\begin{array}{l}\text { Clinical history } \\
\text { Smoker } \\
\text { Dyslipidemia } \\
\text { Hypertension } \\
\text { Family history of cardiovascular event }\end{array}$ & $\begin{array}{c}23(43.4 \%) \\
42(79.2 \%) \\
33(62.3 \%) \\
9(17 \%)\end{array}$ & $\begin{array}{c}23(82.1 \%) \\
22(78.6 \%) \\
14(50 \%) \\
3(10.7 \%)\end{array}$ & $\begin{array}{c}0(0 \%) \\
20(80 \%) \\
19(76 \%) \\
6(24 \%)\end{array}$ & $\begin{array}{l}0.000 \\
0.898 \\
0.051 \\
0.198\end{array}$ \\
\hline $\begin{array}{l}\text { Medical diagnosis } \\
\text { STEMI } \\
\text { NSTEMI } \\
\end{array}$ & $\begin{array}{l}40(75.5 \%) \\
13(24.5 \%)\end{array}$ & $\begin{array}{c}25(89.3 \%) \\
3(10.7 \%) \\
\end{array}$ & $\begin{array}{l}15(60 \%) \\
10(40 \%)\end{array}$ & 0.013 \\
\hline
\end{tabular}


neck, chin, and shoulder area with a $\mathrm{p}<0.01$. The difference in symptomatic manifestation in males and females with ACS is due to the process of chest pain transmission mechanism mediated by sympathetic and vagal nerves activation. In fact, afferent fibers arising from the sympathetic nerves are concentrated along the left anterior coronary artery, while parasympathetic afferents dominate along the right coronary artery and circumflex. Therefore, the problematic part of the artery in ACS can affect the dominance of sympathetic nerves on vagal nerve activation. The activation of the parasympathetic nervous system is associated with manifestations in the form of symptoms such as nausea and vomiting and can characterize pain in patients with a right dominant system, where the tendency of the right dominant coronary system occurs in females. ${ }^{15,19-21}$

The pain felt by male patients was more varied at $<20 \mathrm{~min}$ to $>$ $20 \mathrm{~min}$, while all female patients experienced pain for $>20 \mathrm{~min}$.
These, results are supported by previous studies that in male and female patients, there is a significant difference in terms of duration. ${ }^{22}$ The data showed that 2-30 mins duration is more dominant in male patients with a significance $\mathrm{p}=0.04$, while in females, it is more dominant at $>30$ min with a significance $p=0.007$. These results are also supported by the statement that when myocardial heart has ischemia or infarction, oxygen can supply for at least \pm 20 min, therefore patients with myocardial infarction who experience chest pain duration $>20$ min are considered predictive of ACS diagnosis. Meanwhile, chest pain with a duration of $<5$ min can be stated as less likely to have a diagnosis such as ACS, and has a better prognosis than prolonged pain duration. ${ }^{23}$

The results showed that the pain quality scale in males is heavier (moderate - severe pain scale) than in females (mild - moderate pain scale). Pain quality in males is heavier than in females as indicated by the data that the average pain quality in males is on a scale

Table 2. Chest pain characteristics.

\begin{tabular}{|c|c|c|c|}
\hline Chest pain location & $\begin{array}{l}\text { ACS pa } \\
\text { Male } \\
(\mathrm{n}=28)\end{array}$ & $\begin{array}{l}\text { suffer chest pain } \\
\text { Female } \\
(n=25)\end{array}$ & p \\
\hline Left or middle chest & $27(96.4 \%)$ & $16(64 \%)$ & 0.003 \\
\hline Chest, through to back & $16(57.1 \%)$ & $18(72 \%)$ & 0.260 \\
\hline Chest, radiating to left hand & $2(7.1 \%)$ & $2(8 \%)$ & 0.906 \\
\hline Chest, radiating to neck & $1(3.6 \%)$ & $12(48 \%)$ & 0.000 \\
\hline Chest, radiating to chin & $0(0 \%)$ & $4(16 \%)$ & 0.028 \\
\hline Epigastric & $4(14.3 \%)$ & $5(20 \%)$ & 0.580 \\
\hline $\begin{array}{l}\text { Chest pain trigger } \\
\text { Occurred in regular activities, diminished after resting } \\
\text { Occurred in regular activities, not reduced with resting or ISDN } \\
\text { Occurred in light activities } \\
\text { Occurred when resting }\end{array}$ & $\begin{array}{c}5(17.9 \%) \\
16(57.1 \%) \\
1(3.6 \%) \\
6(21.4 \%)\end{array}$ & $\begin{array}{l}4(16 \%) \\
8(32 \%) \\
2(8 \%) \\
11(44 \%)\end{array}$ & 0.219 \\
\hline $\begin{array}{l}\text { Chest pain duration } \\
>20 \text { minutes } \\
<20 \text { minutes }\end{array}$ & $\begin{array}{c}22(78.6 \%) \\
6(21.4 \%)\end{array}$ & $\begin{array}{c}25(100 \%) \\
0(0 \%)\end{array}$ & 0.014 \\
\hline $\begin{array}{l}\text { Chest pain sensation } \\
\text { Like getting ripped off or sudden } \\
\text { Burnt or stabbed } \\
\text { Crushed or suppressed } \\
\text { Worsen with food/position/inhale }\end{array}$ & $\begin{array}{c}- \\
18(64.3 \%) \\
8(28.6 \%) \\
2(7.1 \%)\end{array}$ & $\begin{array}{c}- \\
9(36 \%) \\
14(56 \%) \\
2(8 \%)\end{array}$ & 0.106 \\
\hline $\begin{array}{l}\text { Chest pain history } \\
\text { Never } \\
\text { Ever, but with lower pain than before } \\
\text { Ever, same as usual } \\
\text { Ever, more severe than before }\end{array}$ & $\begin{array}{l}21(75 \%) \\
1(36 \%) \\
2(7.1 \%) \\
4(14.3 \%)\end{array}$ & $\begin{array}{c}18(72 \%) \\
0(0 \%) \\
0(0 \%) \\
7(28 \%)\end{array}$ & 0.273 \\
\hline $\begin{array}{l}\text { Chest pain level } \\
\text { Low pain } \\
\text { Moderate pain } \\
\text { Severe pain } \\
\end{array}$ & $\begin{array}{c}3(10.7 \%) \\
13(46.4 \%) \\
12(42.9 \%) \\
\end{array}$ & $\begin{array}{l}6(24 \%) \\
16(64 \%) \\
3(12 \%) \\
\end{array}$ & 0.038 \\
\hline
\end{tabular}

ISDN, rest isosorbide dinitrate.

Table 3. Characteristics of atypically symptoms.

\begin{tabular}{|c|c|c|c|c|}
\hline Respondent characteristics & & $\begin{array}{c}\text { ACS patients } \\
\text { Male } \\
(n=28)\end{array}$ & $\begin{array}{l}\text { er chest pain } \\
\text { Female } \\
(n=25)\end{array}$ & p \\
\hline Nausea & $29(54.7 \%)$ & $14(50 \%)$ & $15(60 \%)$ & 0.465 \\
\hline Vomit & $17(32.1 \%)$ & $7(25 \%)$ & $10(40 \%)$ & 0.243 \\
\hline Dyspnea & $34(64.2 \%)$ & $15(53.6 \%)$ & $19(76 \%)$ & 0.089 \\
\hline Abdominal pain & $7(13.2 \%)$ & $0(0 \%)$ & $7(28 \%)$ & 0.003 \\
\hline Diaphoresis & $37(69.8 \%)$ & $25(89.3 \%)$ & $12(48 \%)$ & 0.001 \\
\hline
\end{tabular}


of 4-8, while it is 4-6 for females. ${ }^{22}$ The difference in perceived quality is due to variations in typical pain. Also, females with ACS are more likely to complain of atypical symptoms such as tightness, nausea and pain in the radiating area of the neck and chin, therefore the impression of pain is lower than the typical pain felt in males. ${ }^{24-26}$ Another significant difference is the accompanying symptoms, where males with ACS experienced more diaphoresis as a comorbid symptom, while females experienced more abdominal pain. Therefore, the results are relevant to previous studies that in males, the most significant comorbid symptom for gender differences is diaphoresis, and in females, the most significant symptom was abdominal pain, with a $\mathrm{p}<0.05 .{ }^{16,22}$

\section{Conclusions}

This study showed a significant difference in the characteristics of chest pain symptoms in male and female patients with ACS. Meanwhile, in the aspect of location, duration and quality of chest pain, males have more typical symptoms, while females' symptoms are atypical.

Correspondence: Mifetika Lukitasari, School of Nursing, Faculty of Medicine, Universitas Brawijaya, Jl. Puncak Dieng, Kunci, Kalisongo, Kec. Dau, Malang, East Java 65151, Indonesia.

Tel. +62.341569117 - Fax: +62.341564755.

E-mail: mifetika.fk@ub.ac.id

Key words: Characteristics of symptoms; chest pain; acute coronary syndrome.

Acknowledgements: The authors appreciate the Ministry of Research, Technology and Higher Education of Indonesia, Research and Community Service Brawijaya University and Saiful Anwar Hospital.

Contributions: All authors contributed equally to this article. YOS, HM, SA, conducted the study; ML, supervision, review of the final article. Appreciation to ML \& MSR who kindly and thoughtfully managed this study.

Conflict of interests: The authors declare no conflict of interest.

Funding: This work was supported by the Ministry of Research, Technology and Higher Education of Indonesia and Brawijaya University, Indonesia.

Ethical approval: This study was approved by the Ethics Committee of dr. Saiful Anwar Malang General Hospital, Malang, Indonesia.

Conference presentation: Part of this study was presented at the $1^{\text {st }}$ International Nursing and Health Sciences Symposium, November $13^{\text {th }}$ to $15^{\text {th }} 2020$, Brawijaya University, Malang, Indonesia.

Received for publication: 18 January 2021.

Accepted for publication: 16 March 2021.

C Copyright: the Author(s), 2021

Licensee PAGEPress, Italy

Journal of Public Health Research 2021;10:2242

doi:10.4081/jphr.2021.2242

This work is licensed under a Creative Commons Attribution NonCommercial 4.0 License (CC BY-NC 4.0).

\section{References}

1. WHO. About Cardiovascular diseases. Geneva: WHO; 2015.

2. Dharma S, Andriantoro H, Dakota I, et al. Organisation of reperfusion therapy for STEMI in a developing country. BMJ Open Hert 2015;2:1-7.

3. Price SA, Wilson LM. [Patofisiologi Konsep Klinis ProsesProses Penyakit (Pathophysiology of clinical concepts of disease processes)].[Book in Indonesian]. Jakarta: EGC; 2005.

4. Herlitz J, Wireklintsundstrom B, Bang A, et al. Early identification and delay to treatment in myocardial infarction and stroke: Differences and similarities. Scand J Trauma Resusc Emerg Med 2010;18:48.

5. Rosamond W, Flegal K, Furie K, et al. Heart disease and stroke statistics--2008 update: a report from the American Heart Association Statistics Committee and Stroke Statistics Subcommittee. Circulation 2008;117:e25-146.

6. DeVon HA, Ryan CJ, Rankin SH, et al. Classifying subgroups of patients with symptoms of acute coronary syndromes: A cluster analysis. Res Nurs Health 2010;33:386-97

7. Rosenfeld AG, Knight EP, Steffen A, et al. Symptom clusters in patients presenting to the emergency department with possible acute coronary syndrome differ by sex, age, and discharge diagnosis. Heart Lung 2015;44:368-75.

8. Thuresson M, Jarlov MB, Lindahl B, et al. Symptoms and type of symptom onset in acute coronary syndrome in relation to ST elevation, sex, age, and a history of diabetes. Am Heart J 2005; 150:234-42.

9. Allana S, Khowaja K, Ali TS, et al. Gender differences in factors associated with prehospital delay among acute coronary syndrome patients in Pakistan. J Transcult Nurs 2014;26:48090 .

10. Benjamin EJ, Blaha MJ, Chiuve SE, et al. Heart disease and stroke statistics 2017 update: a Report from the American Heart Association. Circulation 2017;135:e146-603.

11. DeVon HA, Ryan CJ, Ochs AL, et al. Symptoms across the continuum of acute coronary syndromes: Differences between women and men. Am J Crit Care 2008;17:14-25.

12. Shin JY, Martin R, Suls J. Meta-analytic evaluation of gender differences and symptom measurement strategies in acute coronary syndromes. Heart Lung 2010;39:283-95.

13. Mehta LS, Beckie TM, DeVon HA, et al. Acute myocardial infarction in women: a scientific statement from the American Heart Association. Circulation 2016;133:916-47.

14. Martin R, Johnsen EL, Bunde J, et al. Gender differences in patients' attributions for myocardial infarction: implications for adaptive health behaviors. Int J Behav Med 2005;12:39-45.

15. Khan NA, Daskalopoulou SS, Karp I, et al. Sex differences in acute coronary syndrome symptom presentation in young patients. JAMA Int Med 2013;173:1863-71.

16. Van der Meer MG, Backus BE, van der Graaf Y, et al. The diagnostic value of clinical symptoms in women and men presenting with chest pain at the emergency department, a prospective cohort study. PLoS One 2015;10:e116431.

17. Mirzaei S, Steffen A, Vuckovic K, et al. The quality of symptoms in women and men presenting to the emergency department with suspected acute coronary syndrome. J Emerg Nurs 2019;45:357-65.

18. Mackay MH, Ratner PA, Johnson JL, et al. Gender differences in symptoms of myocardial ischaemia. Eur Heart J 2011;32:3107-14.

19. Arora G, Bittner V. Chest pain characteristics and gender in the early diagnosis of acute myocardial infarction. Curr Cardiol Rep 2015;17:5. 
20. Safdar B, Nagurney JT, Anise A, et al. Gender-specific research for emergency diagnosis and management of ischemic heart disease: proceedings from the 2014 Academic Emergency Medicine Consensus Conference Cardiovascular Research Workgroup. Acad Emerg Med 2014;21:1350-60.

21. Canto JG. Symptom presentation of women with acute coronary syndromes. Arch Intern Med 2007;167:2405.

22. Rubini Gimenez M, Reiter M, Twerenbold R, et al. Sex-specific chest pain characteristics in the early diagnosis of acute myocardial infarction. JAMA Intern Med 2014;174:241-9.

23. Shabbir M, Kayani AM, Qureshi O, et al. Predictors of fatal outcome in acute myocardial infarction. J Ayub Med Coll
Abbottabad 2008;20:14-6.

24. Patel H, Rosengren A, Ekman I. Symptoms in acute coronary syndromes: Does sex make a difference? Am Heart J 2004; 148:27-33.

25. Arslanian-Engoren C, Patel A, Fang J, et al. Symptoms of men and women presenting with acute coronary syndromes. Am J Cardiol 2006;98:1177-81.

26. Manfrini O, Ricci B, Cenko E, et al. Association between comorbidities and absence of chest pain in acute coronary syndrome with in-hospital outcome. Int J Cardiol 2016;217:S3743. 